\title{
ENTOMOFAUNA OF FOUR SPOTS OF CHITTAGONG UNIVERSITY CAMPUS AND THEIR RELATIVE ABUNDANCE AND DIVERSITY
}

\author{
Nasiruddin, M. and F. A. Shiuli \\ Department of Zoology, University of Chittagong, Chittagong 4331, Bangladesh
}

\begin{abstract}
Relative abundance and diversity of insects were studied in the four spots of Chittagong University Campus, from October 2015 to September 2016. The studied insect orders were- Odonata, Orthoptera, Coleoptera, Hymenoptera and Lepidoptera. Two families under Odonata, four under Orthoptera, five under Coleoptera, three families under Hymenoptera and eight under Lepidoptera were examined from the four study spots. Among these, sixteen species of Odonata, eight species of Orthoptera, Coleoptera and Hymenoptera in each and 32 Lepidoptera species were identified. Highest numbers of insects (276) was collected in April'16 and December'15 whereas lowest numbers of insects (201) were collected in October'15. The highest abundance (906) of insects was found in Spot 3 (Hilly area), medium (785) in Spot 1 (Pond area) and lowest (642) and (648) in Spot 2 (Garden area) and Spot 4 (Artificial forest area), respectively. Lepidoptera (1217) was the most dominant order in the four studied spots followed by Odonata (636), Coleoptera (395), Hymenoptera (381) and Orthoptera (352). The average highest species richness, species diversity and species evenness were observed in October'15 $(2.40 \pm 0.11)$, August'16 $(2.22 \pm 0.03)$ and August'16 $(0.96 \pm 0.01)$, respectively and lowest in April'16 (2.18 \pm 0.04$)$, April'16 (1.98 \pm 0.07$)$ and April'16 (0.85 \pm 0.03$)$, respectively. During the study period, the highest species richness was observed in Spot 2 and Spot $4(2.32 \pm 0.03)$ and lowest in Spot $3(2.13 \pm$ 0.02); the highest species diversity was observed in Spot 3 (2.16 \pm 0.02$)$ and lowest in Spot 1 and Spot $2(2.04 \pm$ $0.03)$; and the highest species evenness was observed in Spot $3(0.93 \pm 0.01)$ and lowest in Spot 1 and Spot $2(0.88$ \pm 0.01 ). Abundance and diversity of insects were dependent on seasonal fluctuation, and also on ecological and environmental conditions.
\end{abstract}

Key words: Entomofauna, ecological area, abundance, diversity, diversity indices.

\section{INTRODUCTION}

Insects are the most diverse group of organisms of the planet, including more than a million described species and representing more than half of all known living organisms. Biodiversity, a contraction of 'Biological diversity', generally refers to the variety and variability of life on earth. It is a measure of variety of organisms present in different ecosystems. Insect biodiversity accounts for a large proportion of all biodiversity on the planet. Of the described species, insects comprise 900,000 species or $72.8 \%$ of all the animals (Ross 1965). One of the major features of insects is their extraordinary diversity in terms of numbers and morphological forms. The warm and humid climate of Bangladesh is favourable to lower organisms, especially the insect and is rich in different types of entomofauna.

EI-Moursy et al. (2001) reported insect diversity and abundance on 187 species and subspecies belonging to 49 families represented by 15 orders in Zaranik Protectorate, Egypt. Ahmed et al. (2004) studied on the biodiversity of insects associated with sugarcane crop in Faisalabad, Pakistan. James (2011) listed 12 orders of insects amongst which Diptera was the most dominant in Rajshahi University Campus. Khadijah et al. (2013) studied on the diversity and abundance of insect species of Kota Damansara community forest reserve, Selangor, Malaysia in which highest insect diversity was observed in Diptera and highest insect abundance was observed in Blattoidea. Kyermaten et al. (2014) studied a high diversity of insect species in Muni-Pomadze Ramsar site, Ghana. Nasiruddin and Hoque (2015) recorded 61 species of insects belonging to 7 orders in four spots of Chittagong University Campus and.

The present study was under taken to survey the entomofauna of five orders namely Odonata, Orthoptera, Coleoptera, Hymenoptera and Lepidoptera in four ecologically different spots of Chittagong University Campus for one year. 


\section{MATERIAL AND METHODS}

Samplings were done once per month from four ecologically different areas (Spot 1: Pond area, Spot 2: Garden area, Spot 3: Hilly area, and Spot 4: Artificial forest area) of Chittagong University Campus from October 2015 to September 2016. Spot 1 was a square sized pond with rich aquatic vegetation, such as Nymphaea nouchali, Ipomea fistulosa, I. aquatica, Oryza rufipogen etc. and bank of the pond were surrounded with small and big sized trees, such as Ficus carica, Magnifera indica, Arthrocarpus heterophyllus, Musa sapientum, Citrus limon, Acacia auriculaeformis, and some herbs and shrubs. Spot 2 was a garden consisting of flowering plants, such as Rosa sinensis, Tagetes erecta, Ixora coccinea, Castrum nocturnum, Hibiscus rosa-sinensis, Gardenia jasuninoides, Nyctanthes arbor-tristis, Tabarnaemontana divaricata, Murraya paniculata, Dhalia hybrida, Jesminus sambac etc. and plants like Ficus carica, Citrus limon, Acacia auriculaeformis, Albizia lucida, Naphrolepis exaltata etc. Spot 3 was mainly a high land and relatively sunny area covered with various big and small plants, such as Tectona grandis, Swietenia mahagoni, Acacia auriculaeformis, Magnifera indica, Arthrocarpus heterophyllus, Psidium guajava, Carica papaya, Cassia fistula, Lantana camara, Clerodendrum viscosum etc. and plain area with seasonal vegetables and flowering plants. Spot 4 was an artificial forest covered mostly with Swietenia mahagony trees. This spot also have plants like Cocos nucifera, Magnifera indica, Arthrocarpus heterophyllus, Citrus limon, Murraya exotica, Ixora coccinea, Ficus elastic, Rosa sinensis, Tagetes erecta, Celosia cristata, Cosmos bipinnatus etc. Specimens were regularly collected mainly in the morning hours. Collection was made in one spot per day lasted an hour for each spot. Sampling was made by using insect-sweep-net and by hand picking collection. Visual observation and counts were made for those insects that were missed from net practices. The captured insects were chloroformed, killed, sorted, mounted, labeled and preserved following general entomological procedures (Borror et al. 1989).

Identification of insects was done by comparison with previously identified specimens preserved at the Department of Zoology, University of Chittagong. Methods adopted by Bingham (1897, 1903, 1907), Kirby (1914), Maulik (1919), Fraser (1936), Talbot (1975), Richards and Davies (1977), Borrer et al. (1989) and Ahmed et al. (2008a, b, c) were also followed.

Total number of insects per month/per spot/per order was recorded and abundance was calculated by counting. To quantify species diversity the values of three diversity indices was used as Species richness (SR), Species diversity $\left(\mathrm{H}^{\prime}\right)$ and Species evenness $\left(\mathrm{J}^{\prime}\right)$.

The SR per sampling-spot was calculated as per Gleason (1922), Franz (1976) as-

$$
\mathrm{SR}=\mathrm{S}-1 / \log \mathrm{N}
$$

Where $S=$ Total number of species in a sample.

$\mathrm{N}=$ Natural $\log$ of total number of individuals of all species

Shannon-Wiener's species diversity index $\left(H\right.$ or $\left.H^{\prime}\right)$ incorporates both species richness and equitability. The formula of Shannon-Wiener (1949) diversity index is

$$
H^{\prime}=-\sum_{i=1}^{s}\left(p i \log _{2} p i\right)
$$

Where, $s=$ Total number of species in a sample

$p i=$ Proportion of the population $=$ Number of individual of one population $\div$ total individual of the community

Species evenness $\left(J^{\prime}\right)$ is a measure of equitability, a measure how evenly the individuals are distributed among the different species as per Pielou (1966).

$$
\begin{gathered}
J^{\prime}=H^{\prime} / \log _{2} S \\
\text { Where, } \quad J^{\prime}=\text { Species evenness } \\
H^{\prime}=\text { Species diversity } \\
S=\text { Number of species }
\end{gathered}
$$




\section{RESULTS AND DISCUSSION}

A total of 2981 insect specimens were collected during one year study period. The collected specimens were sorted into five major orders. The orders were Odonata, Orthoptera, Coleoptera, Hymenoptera and Lepidoptera. Two families of Odonata, four from Orthoptera, five from Coleoptera, three from Hymenoptera and eight families under Lepidoptera were identified. The study includes 72 species as a whole. These species are listed in Table 1.

Table 1. List of the insects collected during the study period.

\begin{tabular}{|c|c|c|c|}
\hline Order & Family & Scientific name & Common name \\
\hline \multirow[t]{16}{*}{ Odonata } & \multirow[t]{13}{*}{ Libellulidae } & Orthetrum sabina (Drury 1770) & Green marsh hawk \\
\hline & & Orthetrum pruinosum neglectum (Rambur 1842) & Common red skimmer \\
\hline & & Orthetrum cancellatum (Linnaeus 1758) & Black-tailed skimmer \\
\hline & & Orthetrum coerulescens (Fabricius 1787) & Keeled skimmer \\
\hline & & Neurothemis fulvia (Drury 1773) & Fulvous forest skimmer \\
\hline & & Neurothemis tullia tullia (Drury 1773) & Pied-paddy skimmer \\
\hline & & Rhyothemis variegata (Linnaeus 1763) & Common picture wing \\
\hline & & Zyxomma petiolatum (Rambur 1842) & Skimmer \\
\hline & & Potamarcha congener (Rambur 1842) & Blue chaser \\
\hline & & Brachythemis contaminata (Fabricius 1793) & Skimmer \\
\hline & & Trithemis pallidinervis (Kirby 1889) & Dancing drop wing \\
\hline & & Aethriamanta brevipennis (Rambur 1842) & Scarlet marsh hawk \\
\hline & & Diplacodes trivialis (Rambur 1842) & Blue darter \\
\hline & \multirow[t]{3}{*}{ Coenagrionidae } & Ceriagrion fallax (Risso 1914) & Narrow-winged damselfly \\
\hline & & Agriocnemis famina (Brauer 1890) & Narrow-winged damselfly \\
\hline & & Agriocnemis clauseni (Fraser 1922) & Narrow-winged damselfly \\
\hline \multirow[t]{8}{*}{ Orthoptera } & \multirow[t]{5}{*}{ Acrididae } & Oxya chinensis (Thunberg 1825) & Short horned grasshopper \\
\hline & & Oxya velox (Fabricius 1787) & Paddy field grasshopper \\
\hline & & Locusta migratoria (Linnaeus) & Locust \\
\hline & & Acrida exaltata (Walker 1859) & Short horned grasshopper \\
\hline & & Traulia cachara (Kirby) & Short horned grasshopper \\
\hline & Tettigoniidae & Scudderia sp. (Stal 1873) & Katydid \\
\hline & Tetrigidae & Hedotettix gracillis (de Haan 1842) & Grouse locust \\
\hline & Gryllidae & Euscyrtus sp. (Guerin 1844) & Long horned urchunga \\
\hline \multirow[t]{8}{*}{ Coleoptera } & \multirow[t]{2}{*}{ Crysomelidae } & Aulacophora sp. (Dejean 1836) & Pumpkin beetle \\
\hline & & Aspidomorpha sp. (Hope 1840) & Tortoise beetle \\
\hline & \multirow[t]{3}{*}{ Scarabaeidae } & Phyllophaga crinita (Burmeister 1855) & June beetle \\
\hline & & Euchlora sp. (Fabricius 1773) & Ground beetle \\
\hline & & Caccobius sp. (Thomson 1863) & Dung beetle \\
\hline & Meloidae & Mylabris cichorii (Linnaeus 1758) & Blister beetle \\
\hline & Coccinellidae & Epilachna sp.(Chevrolat 1837) & Plant-eating lady beetle \\
\hline & Elateridae & Alaus sp. (Eschscholtz 1829) & Click beetle \\
\hline \multirow[t]{8}{*}{ Hymenoptera } & \multirow[t]{4}{*}{ Vespidae } & Vespa assamensis (Meade-waldo 1913) & Asian giant hornet \\
\hline & & Vespa tropica (Linnaeus 1758) & Greater banded hornet \\
\hline & & Vespa mandarinia (Smith 1852) & Asian giant hornet \\
\hline & & Bembix rostrata (Linnaeus 1758 ) & Wasp \\
\hline & \multirow[t]{3}{*}{ Apidae } & Apis cerana (Fabricius 1793) & Asiatic honey bee \\
\hline & & Xylocopa aestuans (Latreille 1802) & Large carpenter bee \\
\hline & & Anthophora zonata (Strand 1913) & Blue-banded bee \\
\hline & Formicidae & Formica familiaris (Smith 1860) & Wood ant \\
\hline \multirow[t]{5}{*}{ Lepidoptera } & \multirow[t]{5}{*}{ Danaidae } & Danaus genutia (Cramer 1779) & Striped tiger \\
\hline & & Danaus chrysippus (Linnaeus 1758) & Plain tiger \\
\hline & & Parantica aglea (Stoll 1782) & Glassy tiger \\
\hline & & Euploea core (Cramer 1780) & Common crow \\
\hline & & Euploea mulciber (Cramer 1777) & Striped blue crow \\
\hline
\end{tabular}




\begin{tabular}{|c|c|c|}
\hline & Euploea klugii (Moore 1857) & Blue crow \\
\hline Papilionidae & $\begin{array}{l}\text { Troides aecus (Felder and Felder 1860) } \\
\text { Troides helena (Felder and Felder 1865) } \\
\text { Papilio memnon (Linnaeus 1758) } \\
\text { Papilio polytes (Cramer 1775) }\end{array}$ & $\begin{array}{l}\text { Golden birdwing } \\
\text { Common birdwing } \\
\text { Great mormon } \\
\text { Common mormon }\end{array}$ \\
\hline Pieridae & $\begin{array}{l}\text { Catopsilia pomona (Fabricius 1775) } \\
\text { Catopsilia florella (Bingham 1907) } \\
\text { Gardaca harina (Moore 1906) } \\
\text { Eurema hecabe (Linnaeus 1758) } \\
\text { Leptosia nina (Fabricius 1793) } \\
\text { Delias descombesi (Boisduval 1836) } \\
\text { Appias albino (Binghom 1907) } \\
\text { Pieris canidia (Evans 1912) }\end{array}$ & $\begin{array}{l}\text { Common emigrant } \\
\text { African emigrant } \\
\text { Tree yellow } \\
\text { Common grass yellow } \\
\text { Psyche } \\
\text { Red-spot jezebel } \\
\text { Common albatross } \\
\text { Indian cabbage white } \\
\end{array}$ \\
\hline Nymphalidae & $\begin{array}{l}\text { Lebadea martha (Fabricius 1787) } \\
\text { Ariadne ariadne (Fruhstorfer 1899) } \\
\text { Tanaecia lepidea (Butler 1868) } \\
\text { Junonia atlites (Linnaeus 1763) } \\
\text { Jononia lemonias (Linnaeus 1758) } \\
\text { Junonia almana (Linnaeus 1758) } \\
\text { Precis iphita (Cramer 1779) } \\
\text { Neptis hylas (Moore 1758) } \\
\text { Pantoporia hordonia (Stoll 1790) } \\
\end{array}$ & $\begin{array}{l}\text { Knight } \\
\text { Angled castor } \\
\text { Grey count } \\
\text { Grey pansy } \\
\text { Lemmon pansy } \\
\text { Peacock pansy } \\
\text { Chocolate pansy } \\
\text { Common sailor } \\
\text { Common lascar } \\
\end{array}$ \\
\hline Lycaenidae & $\begin{array}{l}\text { Arhopala centaurus (Moore 1883) } \\
\text { Euchrysops cnejus (Fabricius 1798) }\end{array}$ & $\begin{array}{l}\text { Centaur oakblue } \\
\text { Gram blue }\end{array}$ \\
\hline Hesperiidae & Tagiades japetus (Moore 1865) & Common snow flat \\
\hline Satyridae & Lethe europa (Fabricius 1775) & Bamboo tree brown \\
\hline Riodinidae & Zemeros flegyas (Cramer 1780) & Punchinello \\
\hline
\end{tabular}

During the study period, a total of 2981 insects was collected of which maximum number (276, 9.26\%) was collected in December'15 and April'16, and minimum number $(201,6.74 \%)$ was collected in October'15. The insects were found dominant in January'16, March'16 and November'15. Insect abundance was lower in the month of July'16 and October'15. Moderate abundance of insects was found in the rest of the months (Table 2).

Table 2. Number of collected insects per month during the study period from October 2015 to September 2016.

\begin{tabular}{|c|c|c|c|c|c|c|}
\hline \multirow[t]{2}{*}{ Month } & \multicolumn{5}{|c|}{ Order } & \multirow[t]{2}{*}{ Total } \\
\hline & Odonata & Orthoptera & Coleoptera & Hymenoptera & Lepidoptera & \\
\hline Oct' 15 & 57 & 28 & 26 & 33 & 57 & $201(6.74 \%)$ \\
\hline Nov' 15 & 62 & 25 & 36 & 32 & 111 & $266(8.92 \%)$ \\
\hline Dec' 15 & 59 & 36 & 30 & 30 & 121 & $276(9.26 \%)$ \\
\hline Jan' 16 & 52 & 38 & 25 & 32 & 118 & $265(8.89 \%)$ \\
\hline Feb' 16 & 44 & 20 & 38 & 37 & 117 & $256(8.59 \%)$ \\
\hline Mar' 16 & 47 & 21 & 47 & 37 & 115 & $267(8.95 \%)$ \\
\hline Apr' 16 & 39 & 28 & 46 & 30 & 133 & $276(9.26 \%)$ \\
\hline May' 16 & 45 & 28 & 27 & 22 & 112 & $234(7.85 \%)$ \\
\hline Jun' 16 & 40 & 32 & 25 & 37 & 101 & $235(7.88 \%)$ \\
\hline Jul' 16 & 50 & 36 & 30 & 29 & 73 & $218(7.31 \%)$ \\
\hline Aug' 16 & 51 & 37 & 40 & 33 & 78 & $239(8.02 \%)$ \\
\hline Sep' 16 & 90 & 23 & 25 & 29 & 81 & $248(8.32 \%)$ \\
\hline Total & $636(21.34 \%)$ & $352(11.81 \%)$ & $395(13.25 \%)$ & $381(12.78 \%)$ & $1217(40.83 \%)$ & $2981(100 \%)$ \\
\hline
\end{tabular}

A total of $636(21.34 \%)$ odonates, $352(11.81 \%)$ orthopterans, 395 (13.25\%) coleopterans, 381 $(12.78 \%)$ hymenopterans and $1217(40.82 \%)$ lepidopterans were collected during the study period (Table 2). Insects of all orders were found more or less in almost all the months. Lepidoptera were the 
most abundant insect order in all the months. On the other hand, Orthoptera was the lowest abundant insect order during the study period (Table 2).

Among 2981 collected insects, 785 (26.33\%) from Spot 1, 642 (21.54\%) from Spot 2, $906(30.39 \%)$ from Spot 3 and 648 (21.74\%) from Spot 4 were collected. The highest abundance was found in Spot 3 and lowest in Spot 2 and Spot 4 (Fig. 1b). The order wise distribution of the collected insects per study spots is shown in Fig. 1a. Lepidoptera was the most abundant order in all the four spots whereas Orthoptera was less abundant. Lepidopteran was collected 317 from Spot 1, 289 from Spot 2, 345 from Spot 3, and 266 from Spot 4. In case of orthopteran, Spot 3 (133) was most dominant followed by Spot 1(80), Spot 4(73) and Spot 2(66).

Insects of Lepidoptera and Odonata were seen throughout the year. Insects of Orthoptera, Coleoptera and Hymenoptera were scatteredly available around the year. Lepidopterans and odonates were mostly found in this Spot 1 and Spot 4. Hymenopterans, coleopterans and orthopterans were found comparatively low numbers in Spot 2 (Fig. 1a). During the present study, some species were collected regularly, while others were rare. Such findings are consistent with many community studies, which show that a small number of species dominates the community, whilst the majority of species are relatively rare (El-Moursy et al. 1999).

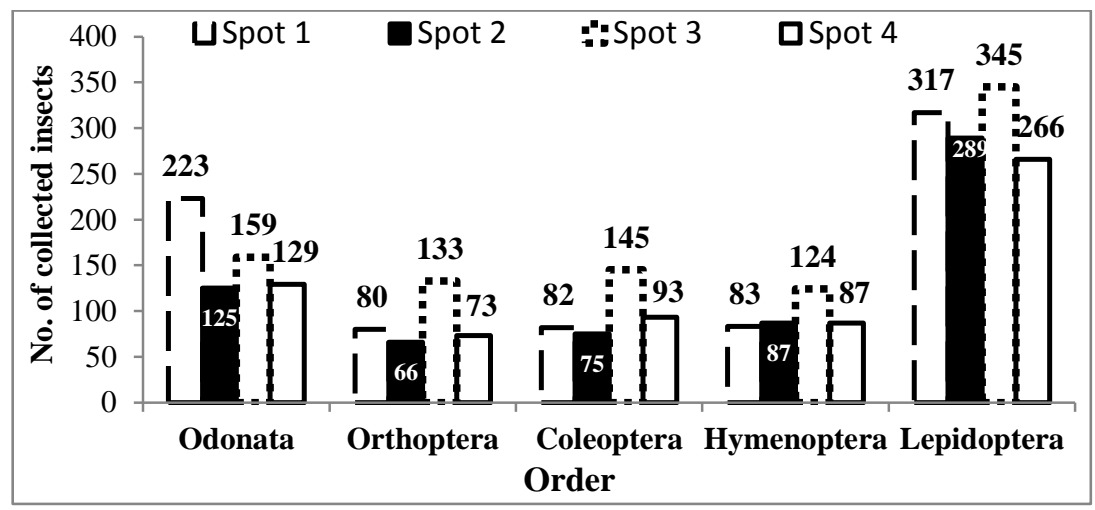

a.

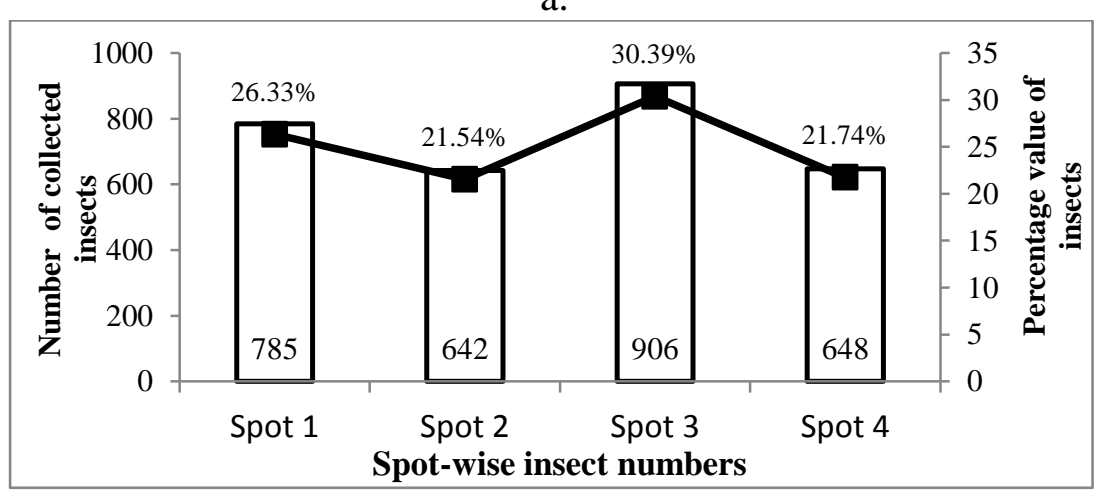

b.

Fig. 1. Number of collected insects during the study period: a. order-wise insect numbers, b. spot-wise insect numbers.

Spot 3 was the natural breeding grounds and food source of butterflies, bees, wasps, beetles and grasshoppers. That's why the highest number of species captured at this site. A large number of dragonflies and damselflies were collected from Spot 1, whereby abundance was high because of the water body and surrounding vegetative area. In Spot 2 abundance of butterflies, bees and wasps was high due to presence of flowering plants. Due to insufficient light with forest and grassland, insect abundance was lower in Spot 4 than the other three spots. 
The environmental factors (both biotic and abiotic) like temperature, humidity, rainfall, vegetation and food sources directly affect the diversity and distribution of insect populations, which is also supported by Morais et al. (1999), Kittelson (2004), Bispo and Oliveira (2007) and Goldsmith (2007). The influence of humidity on density and diversity in environment is likely to be an indirect effect operating via effects on availability. The differences could be the result of habitat and microhabitat differences among the sites.

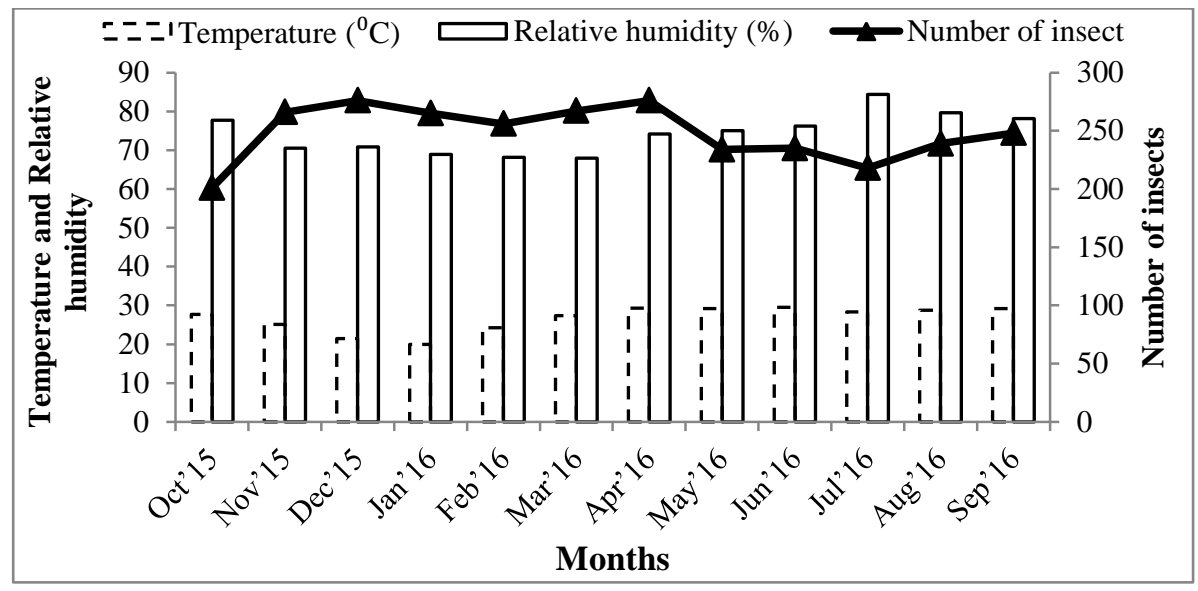

Fig. 2. Month-wise hygro-thermographic (RH and temperature) records and the insect abundance in the experimental spots.

During twelve month study period, the highest temperature was recorded in June' $16\left(29.5^{\circ} \mathrm{C}\right)$ and lowest in January'16 $\left(19.9^{\circ} \mathrm{C}\right)$. The highest relative humidity was found in July'16 $(84.42 \%)$ and lowest in March'16 (67.97\%) (Fig. 2). Cumulative figure of the insect-captures (total number of insect captured) in the experimental spots shows two peaks during the study period. One peak was in the month of December'15 and another peak was in the month of April'16. The capture-peaks were not correlated with records of the temperature and the relative humidity peaks. For the temperature and the relative humidity, the peaks were in the month of June'16 and July'16, respectively. The relative humidity peak was found to take about one month time after the temperature peak appeared in the area of the experimental spots. The insect-captures peaks are found to appear within the range of $21.5^{\circ} \mathrm{C}$ to $29.3^{\circ} \mathrm{C}$ temperature while the relative humidity was within the range of $70.84 \%$ to $74.13 \%$ (Fig. 2).

According to James (2011), the most abundant insect order was Orthoptera, second dominant order was Coleoptera and highest population was observed in November when the temperature and relative humidity were $22.98^{\circ} \mathrm{C}$ and $78.63 \%$, respectively. He observed a link among the temperature and relative humidity with the abundance of insect orders. Nasiruddin and Hoque (2015) found Coleoptera as dominant order in almost all the months except January, February, March, November and December. Lepidoptera was the second dominant order which was found in large number in almost all of the months and also in all the studied spots.

During the study period, the highest species richness was observed in October'15 (2.40 \pm 0.11$)$ and lowest in April'16 (2.18 \pm 0.04$)$. Species richness values fluctuated in between $(2.19 \pm 0.06)$ to $(2.32 \pm 0.06)$ in rest of the months. The average highest species diversity was observed August'16 (2.22 \pm 0.03$)$ and lowest in April'16 (1.98 \pm 0.07$)$. Species diversity values fluctuated in between $(2.02 \pm 0.06)$ to $(2.21 \pm$ $0.04)$ in rest of the months. The average highest species evenness was observed in August'16 (0.96 \pm $0.01)$ and lowest in April'16 (0.85 \pm 0.03$)$. Species evenness values fluctuated in between $(0.87 \pm 0.03)$ to $(0.95 \pm 0.02)$ in rest of the months. Species richness $(\mathrm{SR})$, Species diversity $\left(\mathrm{H}^{\prime}\right)$ and Species evenness $\left(\mathrm{J}^{\prime}\right)$ values of the collected insects in the four study areas are given in Table 3. 
Table 3. Monthly fluctuation (Avg. \pm SE) in Species richness $(\mathrm{SR})$, Species diversity $\left(\mathrm{H}^{\prime}\right)$ and Species evenness $\left(\mathrm{J}^{\prime}\right)$ values of the collected insects in the four study spots.

\begin{tabular}{|c|c|c|c|c|c|c|c|c|c|c|c|c|c|c|c|}
\hline \multirow[t]{2}{*}{ Month } & \multicolumn{5}{|c|}{ Species Richness (SR) } & \multicolumn{5}{|c|}{ Species diversity $(\mathrm{H})$} & \multicolumn{5}{|c|}{ Species evenness (J) } \\
\hline & $\begin{array}{c}\text { Spot } \\
10\end{array}$ & $\begin{array}{c}\text { Spot } \\
2\end{array}$ & $\begin{array}{c}\text { Spot } \\
3\end{array}$ & $\begin{array}{c}\text { Spot } \\
4\end{array}$ & Total & $\begin{array}{c}\text { Spot } \\
1\end{array}$ & $\begin{array}{c}\text { Spot } \\
2\end{array}$ & $\begin{array}{c}\text { Spot } \\
3\end{array}$ & $\begin{array}{c}\text { Spot } \\
4\end{array}$ & Total & $\begin{array}{c}\text { Spot } \\
1\end{array}$ & $\begin{array}{c}\text { Spot } \\
2\end{array}$ & $\begin{array}{c}\text { Spot } \\
3\end{array}$ & $\begin{array}{c}\text { Spot } \\
4\end{array}$ & Total \\
\hline Oct' 15 & 2.17 & 2.53 & 2.35 & 2.63 & $\begin{array}{l}2.40 \\
\pm 0.11\end{array}$ & 2.10 & 2.18 & 2.30 & 2.20 & $\begin{array}{l}2.20 \\
\pm 0.04\end{array}$ & 0.91 & 0.94 & 0.99 & 0.95 & $\begin{array}{l}0.95 \\
\pm 0.02\end{array}$ \\
\hline Nov' 15 & 2.11 & 2.23 & 2.13 & 2.37 & $\begin{array}{l}2.21 \\
\pm 0.06\end{array}$ & 2.12 & 2.04 & 2.08 & 2.07 & $\begin{array}{l}2.08 \\
\pm 0.02\end{array}$ & 0.91 & 0.88 & 0.90 & 0.89 & $\begin{array}{l}0.90 \\
\pm 0.01\end{array}$ \\
\hline Dec' 15 & 2.18 & 2.31 & 2.04 & 2.23 & $\begin{array}{l}2.19 \\
\pm 0.06\end{array}$ & 1.99 & 2.02 & 2.14 & 2.04 & $\begin{array}{l}2.05 \\
\pm 0.03\end{array}$ & 0.86 & 0.87 & 0.92 & 0.88 & $\begin{array}{l}0.88 \\
\pm 0.01\end{array}$ \\
\hline Jan' 16 & 2.22 & 2.22 & 2.10 & 2.27 & $\begin{array}{l}2.20 \\
\pm 0.04\end{array}$ & 1.99 & 2.03 & 2.12 & 2.03 & $\begin{array}{l}2.04 \\
\pm 0.03\end{array}$ & 0.86 & 0.88 & 0.91 & 0.88 & $\begin{array}{l}0.88 \\
\pm 0.01\end{array}$ \\
\hline Feb' 16 & 2.16 & 2.24 & 2.15 & 2.33 & $\begin{array}{l}2.22 \\
\pm 0.04\end{array}$ & 1.89 & 2.01 & 2.19 & 2.01 & $\begin{array}{l}2.02 \\
\pm 0.06\end{array}$ & 0.81 & 0.87 & 0.94 & 0.87 & $\begin{array}{l}0.87 \\
\pm 0.03\end{array}$ \\
\hline Mar' 16 & 2.16 & 2.24 & 2.11 & 2.29 & $\begin{array}{l}2.20 \\
\pm 0.04\end{array}$ & 1.98 & 2.03 & 2.13 & 2.06 & $\begin{array}{l}2.05 \\
\pm 0.03\end{array}$ & 0.85 & 0.88 & 0.92 & 0.89 & $\begin{array}{l}0.89 \\
\pm 0.01\end{array}$ \\
\hline Apr' 16 & 2.15 & 2.29 & 2.14 & 2.14 & $\begin{array}{l}2.18 \\
\pm 0.04\end{array}$ & 1.96 & 1.78 & 2.11 & 2.07 & $\begin{array}{l}1.98 \\
\pm 0.07\end{array}$ & 0.84 & 0.77 & 0.91 & 0.89 & $\begin{array}{l}0.85 \\
\pm 0.03\end{array}$ \\
\hline May' 16 & 2.23 & 2.34 & 2.17 & 2.34 & $\begin{array}{l}2.27 \\
\pm 0.04\end{array}$ & 1.98 & 2.02 & 2.10 & 2.03 & $\begin{array}{l}2.03 \\
\pm 0.02\end{array}$ & 0.85 & 0.77 & 0.91 & 0.88 & $\begin{array}{l}0.88 \\
\pm 0.01\end{array}$ \\
\hline Jun' 16 & 2.31 & 2.38 & 2.16 & 2.23 & $\begin{array}{l}2.27 \\
\pm 0.05\end{array}$ & 2.06 & 2.04 & 2.13 & 2.12 & $\begin{array}{l}2.09 \\
\pm 0.02\end{array}$ & 0.89 & 0.88 & 0.92 & 0.91 & $\begin{array}{l}0.90 \\
\pm 0.01\end{array}$ \\
\hline Jul' 16 & 2.30 & 2.43 & 2.17 & 2.37 & $\begin{array}{l}2.32 \\
\pm 0.06\end{array}$ & 2.19 & 2.11 & 2.25 & 2.28 & $\begin{array}{l}2.21 \\
\pm 0.04\end{array}$ & 0.94 & 0.91 & 0.97 & 0.98 & $\begin{array}{l}0.95 \\
\pm 0.02\end{array}$ \\
\hline Aug' 16 & 2.29 & 2.35 & 2.09 & 2.34 & $\begin{array}{l}2.27 \\
\pm 0.06\end{array}$ & 2.18 & 2.17 & 2.24 & 2.28 & $\begin{array}{l}2.22 \\
\pm 0.03\end{array}$ & 0.94 & 0.94 & 0.97 & 0.98 & $\begin{array}{l}0.96 \\
\pm 0.01\end{array}$ \\
\hline Sep' 16 & 2.22 & 2.31 & 2.10 & 2.35 & $\begin{array}{l}2.25 \\
\pm 0.06\end{array}$ & 1.98 & 2.02 & 2.18 & 2.06 & $\begin{array}{l}2.06 \\
\pm 0.04\end{array}$ & 0.85 & 0.87 & 0.94 & 0.89 & $\begin{array}{l}0.89 \\
\pm 0.02\end{array}$ \\
\hline
\end{tabular}

In Spot 1, the highest species richness was observed in June'16 (2.31), species diversity in July'16 (2.19) and species evenness in July'16 and August'16 (0.94). In Spot 2, the highest species richness and species diversity were observed in October'15 (2.53 and 2.18) and species evenness in October'15 and August'16 (0.94). In Spot 3, the highest species richness, species diversity and species evenness were observed in October'15 (2.25, 2.30 and 0.99 respectively). In Spot 4, the highest species richness was observed in October'15 (2.63) and the highest species diversity and species evenness in July'16 and August'16 (2.28 and 0.98) (Table 3).

During the study period, the spot wise fluctuation in Species richness (SR), Species diversity $\left(\mathrm{H}^{\prime}\right)$ and Species evenness $\left(\mathrm{J}^{\prime}\right)$ values was also assessed. The highest species richness was observed in Spot 2 and Spot 4 (2.32 \pm 0.03$)$ and lowest in Spot 3 (2.13 \pm 0.02$)$. The average species richness of Spot 1 was $(2.21 \pm 0.02)$. The highest species diversity was observed in Spot 3 (2.16 \pm 0.02$)$ and lowest in Spot 1 and Spot $2(2.04 \pm 0.03)$. The average species diversity of Spot 4 was $2.10 \pm 0.03$. The highest species evenness was observed in Spot $3(0.93 \pm 0.01)$ and lowest in Spot 1 and Spot $2(0.88 \pm 0.01)$. The average species evenness of Spot 4 was $0.91 \pm 0.01$ (Fig. 3).

It was seen that Spot 2 and Spot 4 were richer of species $(2.32 \pm 0.03)$ with low abundance $(642$ and 648 respectively) and Spot 3 was less rich of species $(2.13 \pm 0.02)$ with high abundance (906) of insects. Spot 3 was most diversified $(2.16 \pm 0.02)$ with highest abundance (906) and Spot 1 and Spot 2 were less diversified (2.04 \pm 0.03$)$ with low abundance (785 and 642 respectively). Spot 3 had most species evenness $(0.93 \pm 0.01)$ due to highest abundance (906) and Spot 1 and Spot 2 had least species evenness $(0.88 \pm$ 0.01) due to low abundance (785 and 642 respectively) of insects (Fig. 1b, 3). 
The average data showed that highest species richness was observed in October'15 $(2.40 \pm 0.11)$ and lowest in April'16 (2.18 \pm 0.04$)$, whilst highest species richness was observed in Spot 2 and Spot 4 (2.32 \pm $0.03)$ and lowest in Spot $3(2.13 \pm 0.02)$. The average highest species diversity was observed in August'16 $(2.22 \pm 0.03)$ and lowest in April'16 (1.98 \pm 0.07$)$, and the highest species diversity was observed in Spot 3 $(2.16 \pm 0.02)$ and lowest in Spot 1 and Spot $2(2.04 \pm 0.03)$. The average highest species evenness was observed in August'16 (0.96 \pm 0.01$)$ and lowest in April'16 $(0.85 \pm 0.03)$, whilst the highest species evenness was observed in Spot $3(0.93 \pm 0.01)$ and lowest in Spot 1 and Spot 2 (0.88 \pm 0.01$)$.

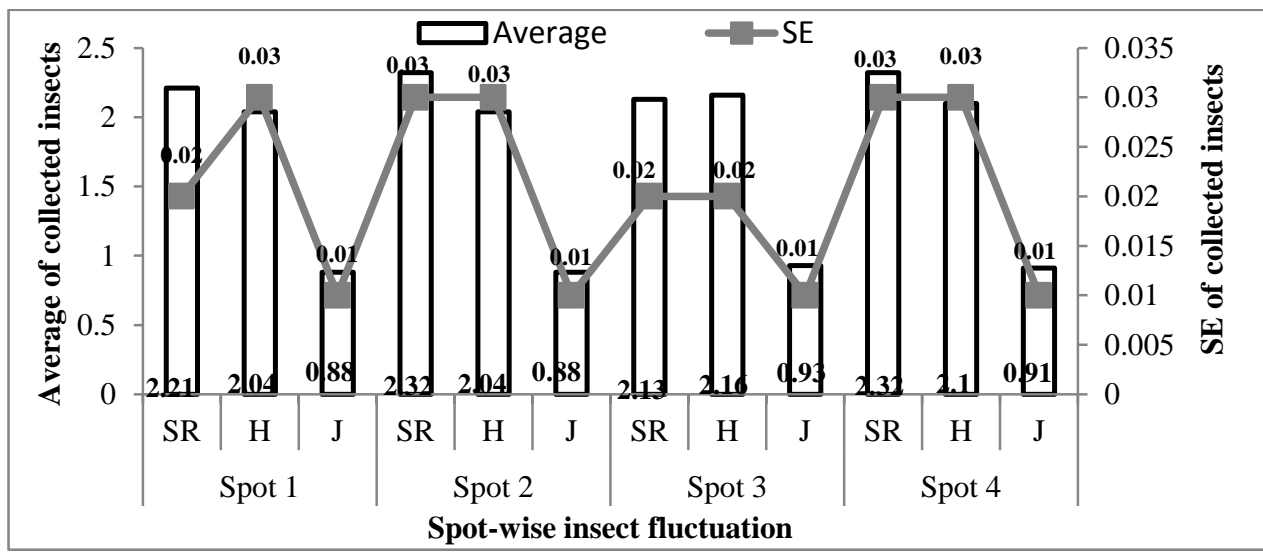

Fig. 3. Spot-wise Species richness (SR), Species diversity ( $\left.\mathrm{H}^{\prime}\right)$, and Species evenness ( $\left.\mathrm{J}^{\prime}\right)$ of the collected insects.

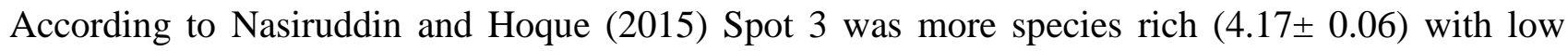
abundance (333) and Spot 2 was less species rich (3.49 \pm 0.04$)$ with high abundance (636) of insects. Spot 2 was most diversified $(2.53 \pm 0.03)$ with highest abundance (636) and Spot 4 was least diversified $(2.34 \pm 0.08)$ with low abundance $(352)$ of insects. Spot 2 had most species evenness $(0.89 \pm 0.01)$ due to highest abundance (636) and Spot 4 had least species evenness $(0.76 \pm 0.03)$ due to low abundance (352) of insects. Hence, insect abundance was positively related with species diversity and species evenness but negatively related with species richness and agreeing with the findings of Nasiruddin and Hoque (2015).

The number of insects fluctuated in different months of the year due to seasonal and environmental factors. Fluctuation in temperature and rainfall played vital role in determining the abundance of individual and overall insect fauna. Variables such as litter depth, litter moisture, humidity and temperature are directly or indirectly related to rainfall and insect population densities also (Wagner et al. 2003, Vineesh et al. 2007). The present study reveals that availability of insects is not only dependent on seasonal fluctuation, but also on other eco-biological aspects. The presence of plants is another cause of the availability. This study also discloses that insect abundance was high in the area occupied by open forest along with flower garden and grassland, and insect abundance was comparatively low in plain land with artificial forest and big trees. Many environmental factors affect diversity of species (Rosenzweig 1995); there is always correlation between structural complexities of habitats and diversity of species (Hawksworth and Kalin-Arroyo 1995); and more diversity is observed in the region with availability of variety of habitats (Ried and Miller 1989).

Dependence of the insect population abundance in relation to the availability of trophic levels in the experimental spots was not examined in the present study. It might be that the temperature and relative humidity variations recorded in the study do not affect significantly on the abundance. But the supply of nutritional sources and the trophic level complexities might have some vital impacts on the population abundance in the experimental spots. It needs further study in the field. 
At present, human beings need to conserve the wealth of nature/species, including insects. They share the planet with us. The sharing deals with our own survival and economy depend on many of the species. We get pleasure or a sense of fascination from these species. We recognize a moral responsibility to act as stewards, showing care and respect for other life forms.

\section{REFERENCES}

Ahmed, A., A. Suhail, Z. Abdin, S. Iftikhar and K. Zahoor. 2004. Biodiversity of insects associated with sugarcane crop in Faisalabad. Pak. Entomol. 26(1): 65-69.

Ahmed, Z. U., S. M. H. Kabir, M. Ahmad, A. T. A. Ahmed, A. K. A. Rahman, E. U. Haque, Z. N. T. Begum, M. A. Hassan and M. Khondker. 2008a. Encyclopedia of Flora and fauna of Bangladesh. Arthropoda: Insecta I. Vol. 19. Asiatic Society of Bangladesh, Dhaka. 275 pp.

Ahmed, Z. U., M. Ahmad, S. M. H. Kabir, A. T. A. Ahmed, A. K. A. Rahman, Z. N. T. Begum, M. A. Hassan and M. Khondker. 2008b. Encyclopedia of Flora and fauna of Bangladesh. Arthropoda: Insecta III. Vol. 21. Asiatic Society of Bangladesh, Dhaka. 460 pp.

Ahmed, Z. U., M. Ahmad, S. M. H. Kabir, A. T. A. Ahmed, Z. N. T. Begum, M. A. Hassan and M. Khondker. 2008c. Encyclopedia of Flora and fauna of Bangladesh. Arthropoda: Insecta IV. Vol. 22. Asiatic Society of Bangladesh, Dhaka. 419 pp.

Bingham, C. T. 1897. The Fauna of British India including Ceylon and Burma. Hymenoptera I. Taylor and Francis, London. 413 pp.

Bingham, C. T. 1903. The Fauna of British India including Ceylon and Burma. Hymenoptera II. Taylor and Francis, London. 506 pp.

Bingham, C. T. 1907. The Fauna of British India including Ceylon and Burma. Butterflies. Taylor and Francis, London. 2: 1-281.

Bispo, P. C. and L. G. Oliveira. 2007. Diversity and structure of Ephemeroptera, Plecoptera and Trichoptera (Insecta) assemblages from riffles in mountain streams of Central Brazil. Revista Brasileira de Zoologia. 24: 283-293.

Borror, D. J., C. A. Triplehorn and N. F. Jonson. 1989. An introduction to the study of Insects. 6th ed. Saunders College Publishing, New York., pp. 665-774.

El-Moursy, A., M. El- Hawagry, M. Abdeldayem and H. Fadl. 2001. Insect Diversity in Zaranik Protectorate, Northern Sinai, Egypt. Egyptian J. Nat. Hist. 3: 62-80.

El-Moursy, A. A., F. Gilbert, S. Zalat and M. S. El- Hawagry. 1999. Foraging behavior of anthracine flies (Diptera: Bombyliidae) in Southern Sinai, Egypt. Egyptian J. Biol. 1: 87-95.

Franz, D. R. 1976. Benthic molluscan assemblages in relation to sediment gradients in northeastern long Island Sound, Connecticut. Malacologia. 15(2): 377-399.

Fraser, F. C. 1936. The Fauna of British India including Ceylon and Burma. Odonata. Vol. II. Today and Tomorrows printers and publishers. $461 \mathrm{pp}$.

Gleason, H. A. 1922. On the relation between species and area. Ecol. 3: 156-162.

Goldsmith, S. 2007. Density of long horned beetles (Coleoptera: Cerambycidae) differs at Different elevations in Hawaiian montane forest. The Southwestern Naturalist. 52: 364-370. 
Hawksworth, D. L. and M. T. Kalin-Arroyo. 1995. Magnitude and Distribution of Biodiversiy. In: V. H. Heywood (ed.). Global Biodiversity Assessment. Cambridge University Press, London, UK., pp. 107-191.

James, F. I. 2011. Abundance and Diversity of Entomofauna in Rajshahi University campus. zoologyworld.com

Khadijah, A. R., A. A. Azidah and S. R. Meor. 2013. Diversity and abundance of insect species at Kota Damansara community forest reserve, Selangor. Sci. Res. Essays. 8(9): 359-374.

Kirby, W. F. 1914. The Fauna of British India, Including Ceylon and Burma: Orthoptera. Vol. 1 (Acrididae). Today and Tomorrows printers and publishers. $276 \mathrm{pp}$.

Kittelson, P. M. 2004. Sources of variation in insect density on Lupinus arboreus Sims: effects of environment, sourse population and plant genotype. The American Midland Naturalist. 152: 323335.

Kyermaten, R., D. A. Lamptey, E. H. Owusu, R. S. Anderson and Y. N. Baidu. 2014. Insect diversity of the Muni- Pomadze Ramsar site: An important site for biodiversity conservation in Ghana. $J$. Insects. $11 \mathrm{pp}$.

Maulik, S. 1919. The Fauna of British India including Ceylon and Burma. Coleoptera,Chrysomelidae. Today and Tomorrows printers and publishers. $439 \mathrm{pp}$.

Morais, H. C., I. R. Diniz and D. M. S. Silvia. 1999. Caterpillar seasonality in a central Brazilian cerrado. Revista de Biologia Tropical. 47: 1025-1033.

Nasiruddin, M. and H. Hoque. 2015. Abundance and diversity of insect fauna in four spots of Chittagong University Campus. J. biodivers. conserv. bioresour. manag. 1(1): 83-92.

Pielou, E. C. 1966. The measurement of diversity in different types of Biological Collections. J. Theort. Biol. 13: 131-144.

Reid, W. V. and K. R. Miller. 1989. Keeping Options Alive: A Scientific Basis for Conserving Biodiversity. World Resources Institute, Washington DC., USA. 128 pp.

Richards, O. W. and R. G. Davies. 1977. Imms' General Textbook of Entomology: Classification and Biology. Vol. 2. 10th ed. Chapman and Hall, London, England. 1354 pp.

Rosenzweig, M. L. 1995. Species Diversity in Space and Time. Cambridge University press. 121 pp.

Ross, H. H. 1965. A Textbook of Entomology. 3rd ed. John Wiley and Sons, Inc. 539 pp.

Shannon, C. E. and W. Wiener. 1949. The Mathematical Theory. University of Illinois press Urbana. $117 \mathrm{pp}$.

Talbot, G. 1975. The Fauna of British India including Ceylon and Burma: Butterflies. Vol. 1. Today and Tomorrows printers and publishers. $600 \mathrm{pp}$.

Vineesh, P. J., S. K. Thomas and K. A. Karmaly. 2007. Community structure and functional group classification of litter ants in the montane evergreen and deciduous forests of Wayanad region of Western Ghats, Southern India. Oriental Insects. 41: 185-200.

Wagner, J. D., W. S. Toft and D. H. Wise. 2003. Spatial stratification in litter depth by forest-floor spiders. Journal of Arachnology. 31: 28-39. 